\title{
TEKNIK PELATIHAN ASERTIF UNTUK MENINGKATKAN ASERTIVITAS TERHADAPPERILAKU SEKSUAL DALAM BERPACARAN
}

\author{
Wardati Humaira \\ Poltekkes Kemenkes Medan \\ e_mail: humaira7180@gmail.com
}

\begin{abstract}
One technique that can be applied to increase assertiveness is assertiveness training. This study aims to determine the effect of assertive training techniques to increase assertiveness on sexual behavior in dating by using a pre-experimental approach with pre-test and post-test Control Group Design as well as non-probability sampling techniques and then analyzed by bivariate and multivariate analysis. The results of the independent sample t test for the level of assertiveness showed that the value of $p=0.001$ with a test value of $t=7.394$, which means that there is an effect of assertive technique training on the assertiveness level of adolescents in sexual behavior. The mean value in the provision of assertive technique training is known to be 4.09 and the mean value to the control is 0.36 , this means that there is a change in the value of the assertiveness level of assertiveness towards sexual behavior in dating.
\end{abstract}

Keywords :Assertive Training, Assertiveness, Sexual Behavior

\section{ABSTRAK}

Salah satu teknik yang dapat diterapkan untukmeningkatkan asertivitas yaitu dengan pelatihan asertif. Penelitian ini bertujuan untuk mengetahui pengaruh teknik assertive training untuk meningkatkan asertivitas terhadap perilaku seksual dalam berpacaran dengan menggunakan pendekatan Preeksperimen denganpre test dan post test Control Group Designsertateknik pengambilan sampel Non Probability Samplingselanjutnya dianalisis dengan analisis bivariat dan multivariat.Hasil uji independent sample t testtingkat asertifitas diketahui nilai $\mathrm{p}=0,001$ dengan nilai uji $\mathrm{t}=7,394$, yang artinya bahwa ada pengaruh pemberian pelatihan teknik asertif terhadap tingkat asertifitas remaja dalam perilaku seksual. Nilai mean pada pemberian pelatihan teknik asertif diketahui sebesar 4,09dan nilai mean pada kontrol sebesar 0,36, hal ini berarti bahwa ada perubahan nilai tingkat asertifitas asertivitas terhadap perilaku seksual dalam berpacaran.

Kata Kunci : Teknik Asertif, Asertifitas, Perilaku Seksual

\section{PENDAHULUAN}

\section{Latar Belakang}

Remaja merupakan salah satu tahap perkembangan yang memiliki ciri khasdi dalam tahap perkembangannya, salah satunya yaitu berkaitan dengan relasi dengan lawan jenis. Dewasa ini bentuk relasi lawan jenis di kalangan remaja sudah semakin mengkhawatirkan, dimana mengarah pada perilaku seksual pranikah. ${ }^{(1)}$

Masalah yang menonjol dikalangan remaja adalah permasalahan seputar TRIAD KRR (Seksualitas, HIV dan AIDS serta NAPZA), rendahnya pengetahuan remaja tentang kesehatan reproduksi remaja dan nilai rata-rata usia kawin pertama perempuan relatif masih rendah yaitu 19,8 tahun. $(2)$

Perilaku seksual yang melanda remaja ini cenderung meningkat. Akibat dari segala dampak yang muncul seperti kehamilan di luar nikah, kawin muda, anakanak lahir diluar nikah, aborsi, penyakit menular seksual, depresi pada wanita yang terlanjur berhubungan seks dan lain sebagainya. ${ }^{(3)}$

\begin{tabular}{rrr}
\multicolumn{2}{c}{ Berdasarkan survei } & diketahui \\
kebanyakan & wanitadan & laki-
\end{tabular} lakimulaiberpacaranpada usia15-17, dengansedikit lebih tinggiproporsibagi perempuandaripada laki-lakimasing-masing 

Vol. 15 No. 3 September - Desember 2020

$43 \%$

dan40\%.

Inimenyiratkanbahwainisiasiuntuk berpacaran lebih cenderungterjadi padausia yang lebihmudapada wanita dibandingkan pria. Sebanyak $24 \%$ wanitamengatakan bahwamereka mulai berkencansebelum mencapai usia15, dibandingkandengan19persen lakilaki.Pararespondenjuga

ditanyajeniskegiatanyang merekalakukan ketikakencan,termasukberpegangan tangan, berciuman, danpetting, dan diketahui bahwamemegangtanganadalah yang paling umum dilakukan yaitu $68 \%$ pada perempuan dan69\% pada laki-laki, berciumanlaki-laki 41\%dan perempuan27persen,danyang melakukan pettinglaki-laki $27 \%$ danperempuan $9 \%$.

Sebagian dari tingkah laku itu memang tidak berdampak apa-apa, terutama jika tidak ada dampak fisik atau sosial yang dapat ditimbulkannya. Tetapi pada sebagian perilaku seksual yang lain, dapat terjadi

Sikap tegas terhadap perilaku seksual pranikah atau disebut juga dengan ketegasan seksual adalah kemampuan untuk bertindak tegas pada hak seksual untuk tidak disalahgunakan dan dapat mengambil keputusan seksual mereka dengan tetap menghormati hak orang lain atau pasangannya, dan mengekspresikan diri dengan jujur dengan cara yang benar tanpa terganggu dengan perasaan cemas sehingga terwujudnya keselarasan dan formula dalam hubungan dengan pasangannya. ${ }^{(6)}$

Asertivitas seksual adalah hak serta kemampuan individu untukmenggambarkan parameter kenyamanan diri individu selama aktivitas seksual, untuk mengkomunikasikankebutuhan sendiri atau keinginan seksual, serta kemampuan individu untuk bersikap tegas mempertahankanhak seksualnya agar tidak dilecehkan dan dapat mengambil keputusan seksualnya dengan tetap memberi penghargaan atas hak orang lain dan tanpa menyakiti orang lain atau pasangannya. ${ }^{(7)}$

Sikap Asertif untuk kelompok remaja sangatdiperlukan dalam menghadapi tekanan remaja sebaya.Tekanan itu berkaitan dengan ajakan untuk terlibatkedalam risiko triad KRR, yaitu seksualitas, HIV/AIDS dan napza. Pengaruh perilaku seksual teman sebaya secara langsung paling besar kehamilan di luar nikah yang dampaknya bisa cukup serius, seperti perasaan bersalah, depresi, marah misalnya pada perempuan yang terpaksa menggugurkan kandungannya.(3)

Riset Kesehatan Dasar (Riskesdas) tahun 2013 menemukan bahwa kehamilan pada usia kurang dari 15 tahun terutama terjadi di perdesaan, meskipun dengan proporsi yang sangat kecil $(0,03 \%)$. Sementara itu, proporsi kehamilan di usia 15-19 tahun adalah sebesar 1,97 persen. ${ }^{(4)}$

Remaja harus mampu menolak pengaruh negatif yang ditawarkan dari lingkungannya. Kemampuan itu berupa keberanian untuk mengatakan "tidak" yang dikenal dengan asertivitas. Asertivitas adalah kemampuan untuk mengekspresikan kenyataan dirinya, yaitu kemampuan untuk mengatakan "tidak" atau "ya" sesuai dengan keadaan sesungguhnya, untuk meminta ekspresi positif atau negatif. ${ }^{(5)}$

memengaruhi perilaku seksual remaja. Pengaruh perilaku seksual teman sebaya secara langsung sebesar 20,2\%, sedangkan pengaruh perilaku seksual teman sebaya secara tidak langsung melalui niat berperilaku seksual sebesar 14,24\%. ${ }^{(8)}$

Konsep assertive training yakni latihan ketegasan yang merupakan kegiatan yangdilakukan guna membantu individu-individu dalam mengembangkan cara-cara berhubungan yang lebih langsung dalam situasi-situasi interpersonal. Orang yang asertif adalah mereka mampu memahami dirinya sendiri dengan baik, sehingga mampu menentukan pilihan, keinginan dan tujuanhidupnya tanpa harus dipengaruhi oleh oranglain. Aspek kepribadian yang erat kaitannya dengan asertivitas memegang peranan penting dalam perkembangan perilaku seksual remaja. ${ }^{(9)}$

Dampak dari pelatihan asertivitas juga dapat menghindarkan remajaterutama remaja perempuan dari tindakan pemaksaan dalam berpacaran.Disamping itu, pelatihan asertivitas dapat meningkatkan kemampuan untukintrospeksi diri. Dalam pelatihan asertivitas, peserta belajar mengenal dirinyaapakah selama ini mereka termasuk individu yang pasif, atau agresif atau asertif, serta melihat seberapa besar tingkat 
asertivitasnya. Pelatihan asertivitas dimungkinkan dapat menurunkan perilaku seksual pranikah. Karena subjek yang diberikan pelatihan asertivitas berkomitmen

Latihan asertif berfokus pada praktek-praktek seperti permainan peran, sehingga individu diharapkan mampu mengatasi ketidakmampuan dalam menampilkan keasertifannya dalam hal ini menolak melakukan perilaku seksual tanpa merasa cemas dan takut akan penilaian orang lain.Berdasarkan hasil penelitian, uji hipotesis menunjukkanbahwa adanya peningkatan asertifitas terhadapperilaku seksual dalam berpacaran yang lebih besar pada siswi kelompok eksperimen setelah diberikannya perlakuan berupa teknik assertive training.(11)

\section{METODE PENELITIAN}

Penelitian ini menggunakan pendekatan quasi eksperimen, menggunakan pre test dan post test one group design.

Penelitian ini dilakukan di SMA Harapan 1 Medan Jalan Imam Bonjol Medan, dilakukan pada bulan Maret sampai bulan Agustus 2018.

Populasi yang dipilih seluruh siswi SMAHarapan1Medan sebanyak580 siswa.Sampel penelitian ini sebanyak 30 orang.

Selanjutnya sampel akan diambil dengan menggunakan kriteria inklusi dan kriteria eksklusi

Prosedur kegiatan penelitian dilakukan meliputi beberapa tahapan, yaitu :

1. Tahap Persiapan

a. Pada tahap ini peneliti melakukan pengurusan perizinan ke lokasi penelitian.

b. Melakukan pengumpulan data awal. Peneliti berkoordinasi dengan guru sekolah untuk

6) Data yang telah dikumpulkan akan dilakukan analisis statistik dengan menggunakan tahapan analisisunivariat dananalisis bivariat.

\section{HASIL}

Berdasarkan tingkat asertifitas sebelum dan sesudah diberikan pelatihan teknik asertif, dapat dilihat distribusi menghindarkan diri dari aktivitasaktivitas seksual yang tidak sesuai dengan aturanaturan yang berlaku. $^{(10)}$

mengetahui identitas responden yang akan mengikuti kegiatan

c. Persiapan bahan ajar yaitu menyiapkan materi tentang asertivitas dalam perilaku seksual

2. Tahap Pelaksanaan

Melakukan kegiatanpenelitian di SMA Harapan 1 Medan. Kegiatan ini dibagai dalam beberapa tahapan, yaitu :

1) Melakukan pretest untuk mengetahui perilaku seksual remaja saat berpacaran, dengan mengisi lembar kuisioner. Responden menceritakan apa yang dialami saat berpacaran

2) Melakukan penyuluhan dengan metode ceramah tentang asertivitas remaja dalam perilaku seksual saat berpacaran kurang lebih 60 menit

3) Responden menonton film asertivitas remaja dalam perilaku seksual saat berpacaran kurang lebih 30 menit.

4) Selanjutnya dalam 3 (tiga) minggu responden diharapkan mempraktekkan apa yang didapat setelah penyuluhan dan pemutaran film.

5) Melakukan posttestuntuk mengetahui perilaku seksual remaja saat berpacaran, dengan mengisi lembar kuisioner. Responden menceritakan apa yang dialami saat berpacaran tingkat asertifitas remaja setelah pemberian pelatihan asertif

responden berdasarkan tingkat asertifitas sebelum dan sesudah diberikan pelatihanteknik asertif, baik pada kelompok intervensi maupun kelompok kontrol. Adanya perubahan pada nilai rerata sebelum dan sesudah pemberian teknik pleatihan asertifitas, namun pada kelompok kontrol juga terjadi perubahan. 
Tabel 1. DistribusiResponden Berdasarkan BerdasarkanTingkat Asertifitas sebelum dan Sesudah Diberikan PelatihanTeknik Asertif

\begin{tabular}{|l|c|c|c|}
\hline $\begin{array}{l}\text { Asertifit } \\
\text { as }\end{array}$ & $\begin{array}{c}\text { Sebelu } \\
\mathbf{m}\end{array}$ & $\begin{array}{c}\text { Sesuda } \\
\mathbf{h}\end{array}$ & Selisih \\
\hline $\begin{array}{l}\text { Interven } \\
\text { si }\end{array}$ & & & \\
\hline $\begin{array}{l}\text { Rerata } \\
\text { (SD) }\end{array}$ & 24,55 & 28,64 & $\begin{array}{c}2,79 \\
(3,527)\end{array}$ \\
\hline Min-max & $18-30$ & $21-33$ & $0-11$ \\
\hline Kontrol & & & \\
\hline $\begin{array}{l}\text { Rerata } \\
\text { (SD) }\end{array}$ & 25,27 & 25,64 & $0,61(0,70$ \\
& $(4,875)$ & $(4,722)$ & $4)$ \\
\hline Min-max & $13-13$ & $14-33$ & $0-2$ \\
\hline
\end{tabular}

Berdasarkan hasil uji paired ttest diketahuipengaruh pelatihan teknik asertif terhadap tingkat asertifitas sebelum dan sesudahyaitu dengan nilai $\mathrm{p}=0,000$ $(\mathrm{p}<0,05)$, maka dapat disimpulkan bahwa ada pengaruh pemberian pelatihan teknik asertifterhadap perubahan tingkat asertifitas remaja.

Selanjutnya pada kontrolterjadi perubahan nilai rata-rata tingkat asertifitas sebelum dan sesudah, dengan nilai $\mathrm{p}=0,000$ ( $>0,05)$, maka dapat disimpulkan bahwa ada perubahannilai rata-rata sebelum dan sesudah pada kontrol,namun perubahan nilai

Tabel 3. Pengaruh Pelatihan Asertif untuk Meningkatkan Asertifitas Remaja dalam Perilaku Seksual Berpacaran

\begin{tabular}{|c|c|c|c|c|c|}
\hline \multirow{2}{*}{$\begin{array}{c}\text { Tingka } \\
\mathbf{t} \\
\text { Asertifi } \\
\text { tas }\end{array}$} & \multirow{2}{*}{$\begin{array}{c}\text { Me } \\
\text { an }\end{array}$} & \multirow[t]{2}{*}{$T$} & \multirow[t]{2}{*}{$P$} & \multicolumn{2}{|c|}{$95 \%$ CI } \\
\hline & & & & $\begin{array}{c}\text { Low } \\
\text { er }\end{array}$ & $\begin{array}{c}\text { Upp } \\
\text { er }\end{array}$ \\
\hline Interve & 4,09 & 7,3 & 0,0 & 2,72 & 4,73 \\
\hline nsi & & 94 & 01 & 0 & 4 \\
\hline Kontrol & 0,36 & & & $\begin{array}{c}2,70 \\
3\end{array}$ & $\begin{array}{c}4,75 \\
1\end{array}$ \\
\hline
\end{tabular}

\section{PEMBAHASAN}

Tekhnik pelatihan asertif merupakan suatu strategi terapi dari pendekatan perilaku yang digunakan individu untuk dapat memecahkan masalah rata-rata tidak sebesar dibandingkan dengan nilai rata-rata responden yang diberikan pelatihan asertif.

Tabel 2. PengaruhPelatihan Teknik Asertif Terhadap Tingkat Asertifitas

\begin{tabular}{|l|c|c|c|c|}
\hline \multirow{2}{*}{$\begin{array}{c}\text { Pelatihan } \\
\text { Teknik } \\
\text { Asertif }\end{array}$} & \multicolumn{4}{|c|}{ Tingkat Asertifitas } \\
\cline { 2 - 5 } & Mean & $\boldsymbol{\Delta}$ & $\boldsymbol{T}$ & $\boldsymbol{P}$ \\
\hline Intervensi & & & & \\
\hline Sebelum & 24,55 & 4,09 & $\begin{array}{c}- \\
8,625\end{array}$ & 0.000 \\
\hline Sesudah & 28,64 & & & \\
\hline Kontrol & & & & \\
\hline Sebelum & 25,27 & 0,37 & -3807 & 0.001 \\
\hline Sesudah & 25,64 & & & \\
\hline
\end{tabular}

Hasil uji independent sample $t$ testtingkat asertifitas diketahui nilai $\mathrm{p}=$ 0,001 dengan nilai uji $t=7,394$, yangartinya bahwa ada pengaruh pemberian pelatihan teknik asertif terhadap tingkat asertifitas remaja dalam perilaku seksual.

Nilai mean pada pemberian pelatihan teknik asertifdiketahui sebesar 1,00dan nilai mean pada kontrol sebesar 0,71 , hal ini berarti bahwa ada perubahan nilai tingkat asertifitas terhadap perilaku seksual dalam berpacaran.

dalam proses konseling. Tekhnik pelatihan asertifjuga merupakan suatu program belajar mengekspresikan perasaandan pemikirannya secara jujur dan tidak membuat orang lain terancam.(12)

Berpacaran dapat memberikan kontribusi positif maupun negatif bagi remaja yang berpacaran. Hasil positif yang didapatkan oleh remaja yang berpacaran adalah ketika mereka dihadapkan oleh suatu konflik, maka jalan untuk menyelesaikan konflik adalah dengan pengendalian diri diantara mereka. Pengendalian diri tersebut diantaranya yaitu kesabaran dan berpikir positif.(13)

Adapun kontribusi negatif yang muncul akibat berpacaran adalah menjadi malas belajar, berani melawan orang tua demi pacar, terjadinya aktivitas aktivitas 
seksual seperti berpelukan, berciuman, petting seks pranikah yang mengakibatkan munculnya masalah kehamilan yang tidak dikehendaki dan masalah aborsi serta kekerasan dalam berpacaran. Perilaku negatif pacaran yang sering dilakukan remaja adalah ciuman. Pengaruh lingkungan, media informasi dan film adalah salah satu yang menyebabkan perilaku

rata sebelum dan sesudah pada kontrol,namun perubahan nilai rata-rata tidak sebesar dibandingkan dengan nilai rata-rata responden yang diberikan pelatihan asertif.Hal ini sesuai menurut Amaliyahbahwa terdapat lebih banyak peningkatan yang terjadi setelah pelaksanaan teknik assertive training pada kelompok eksperimen.(11)

Berdasarkan hasil uji independent sample $t$ testdiketahui ada pengaruh pemberian pelatihan teknik asertif terhadap tingkat asertifitas remaja dalam perilaku

Melalui pelatihan asertivitas ini remaja juga dilatih untuk mengungkapkan pikiran dan perasaan serta mampu memberikan respon-respon penolakan dan permintaan kepada sang pacar.

Konsepassertive training yakni latihan ketegasan yang merupakankegiatan yang dilakukan guna membantuindividuindividu dalam mengembangkancara-cara berhubungan yang lebih langsungdalam situasi-situasi interpersonal.Hal tersebut di atas mengindikasikanbahwa semakin berkembang asertif seorangsiswa, maka kecenderungan pergaulan bebasjuga akan semakin menurun.(9)

Remaja perlu bersikap tegas atau asertif dalam menolak ajakan teman sebaya yang tidak rasional. Latihan asertif dapat meningkatkan nilai yang ada pada diri sendiri dan orang lain, meningkatkan harga diri, mengurangi kecemasan, meningkatkan kemampuan seseorang dalam membuat keputusan hidup, dan mengkespresikan sesuatu melalui gerakan tubuh. (14)

Sejalan dengan penelitian Harsanti, menunjukkan bahwa perilaku seksual beresiko pada kelompok perlakuan sebelum diberikan latihan asertif adalah 40,0\% orangberesiko, dan sebanyak $60,0 \%$ ) orang tidak beresiko, sedangkan setelah diberikan latihan asertif data menunjukkan sebanyak tersebut menjadi kebiasaan yang dilakukan oleh remaja ketika pacaran.

Berdasarkan hasil diketahui ada pengaruh pemberian pelatihan teknik asertifterhadap perubahan tingkat asertifitas remaja.Selanjutnya pada kontrolterjadi perubahan nilai rata-rata tingkat asertifitas sebelum dan sesudah pada kontrol, maka dapat disimpulkan bahwa tidak ada perubahannilai rataseksual. Hal ini dapat dilihat bahwa ada perubahan nilai tingkat asertifitas terhadap perilaku seksual dalam berpacaran pada siswa SMA Harapan 1 Medan.

Metode untuk meningkatkan perilaku asertif salah satunya yaitu pelatihan asertivitas. Pelatihan asertivitas adalah pelatihan yang dirancang untuk membimbing manusia untuk menyatakan, merasa, dan bertindak pada asumsi bahwa mereka memiliki hak untuk menjadi dirinya sendiri tanpa harus mengesampingkan hak orang

lain.

$35,6 \%$ orang beresiko dan $64,4 \%$ orang tidak beresiko, diperoleh $\mathrm{p}$ value $(0,021)<\mathrm{a}$ $(0,05)$ yang berarti ada pengaruh latihan asertif terhadap perilaku seksual beresiko remaja.

Hasil penelitian Tholense yang meneliti tentang hubungan asertivitas seksual dan perilaku seksual pranikah beserta bentuk-bentuk dari perilaku seksual pranikah, dimana perilaku seksual pranikah tersebut ialah kissing, necking, petting serta intercourse. menunjukkan bahwa perilaku seksual pranikah dalam bentuk kissingmemiliki hubungan yang negatif dengan asertivitas seksual, yang berarti semakin tinggi asertivitas seksual pada subjek maka semakin rendah perilaku seksual pranikah dalam bentuk kissing pada subjek. Apabila bentuk perilaku seksual pranikah paling awal sudah memiliki hasil yang negatif, maka hampir dapat dipastikan bahwa hasil dari penelitian pada perilaku seksual pranikah paling akhir yaitu bentuk intercourse memiliki hasil yang negatif. Hasil tersebut menunjukkan bahwa perilaku seksual pranikah dalam bentuk intercourse memiliki hubungan yang negatif dengan asertivitas seksual, yang berarti semakin tinggi asertivitas seksual pada subjek maka semakin rendah perilaku seksual pranikah dalam bentuk intercourse pada subjek. Hal 
ini juga berarti bahwa subjek penelitian memiliki kemampuan untuk bertindak asertif dalam hal seksual terkait keempat bentuk perilaku seksual pranikah tersebut.

Remaja yang memiliki sikap asertif dapat bertindak tegas menolak perilaku seksual dihadapinya. Semakin remaja bersikap asertif maka semakin kuat kemampuan remaja untuk menolak ajakan perilaku seksual tersebut.

\section{KESIMPULAN DAN SARAN}

Berdasarkan hasil penelitian maka dapat dibuat kesimpulan, ada pengaruh pemberian pelatihan teknik asertif terhadap tingkat asertifitas terhadap perilaku seksual dalam berpacaran pada siswa SMA Harapan 1 Medan.

\section{DAFTAR PUSTAKA}

1. Nasri D, Koentjoro. Pelatihan Asertivitas Normatif Terhadap Perilaku Seksual Pranikah Pada Wanita Bermasalah Sebagai Upaya Preventif. Jurnal Ilmiah Psiklogi Terapan. 2015;03(02):268-86.

2. Fitriani, Iin. Pengembangan Metode Pelatihan dengan Problem Card dalam Peningkatan Pengetahuan Dan Sikap Remaja Tentang Kesehatan Reproduksi. Unnes Journal Of Public Health. 2016;5.

3. Sarwono. Psikologi Remaja Definisi Remaja. Revisi. Jakarta: Rajagrafindo Persada; 2012.

4. Kemenkes Ri, Badan Penelitian dan Pengembangan Kesehatan. Riset Kesehatan Dasar. 2013.

5. Nabila Ai, Nugroho Aa. Pengaruh Pemberian Pelatihan Asertivitas Terhadap Kecenderungan Kenakalan Remaja Pada Siswa Kelas X Sekolah Menengah Kejuruan (Smk) Bhinneka Karya Surakarta. Uns-F.Kedokteran Jur Psikologi;36.

6. Fathimiyah I, Amartha Va, Rahayuwati L, Rafiyah I. Self-Esteem, Assertiveness, and Sexualbehavior In
Perilaku seksual pranikah yang saat ini sering terjadi pada remaja, diharpkan dapat diatasi dengan menerapkan sikap asertif kepada remaja.

Selanjutnya disarankan kepada pihak sekolah untuk memasukan edukasi tentang perilaku seksual, sekaligus memasukkan teknik asertif dalam praktek pembelajaran di sekolah asertif terhadap tingkat asertifitas terhadap perilaku seksual dalam berpacaran pada siswa SMA Harapan 1 Medan. Selanjutnya disarankan kepada pihak sekolah untuk memasukan edukasi tentang perilaku seksual, sekaligus memasukkan teknik asertif dalam praktek pembelajaran di sekolah.

Adolescent Girls. In: Conference Book International Conference On Health Care And Management, "Evidence To Inform Action On Supporting And Implementation Of SDGS." Bandung; 2018.

7. Tholense N, Rahardjo W. Asertivitas Seksual dan Perilaku Seks Pranikah Pada Mahasiswa. Jurnal Psikologi Ulayat. 2013;1:6.

8. Humaira W. Pengaruh Pola Asuh Orang Tua dan Teman Sebaya Terhadap Asertifitas Remaja Dalam Perilaku Seksual di SMP Negeri I Hinai Kecamatan Hinai Kabupaten Langkat Tahun 2014. Jurnal Ilmiah Pannmed. 10(01):106-10.

9. Hasbahuddin H, Fithrayani A, Bakhtiar Mi. Assertive Traininguntuk Mengurangi Kecenderungan Pergaulan Bebas. J Ijolec. 2019 Feb 11;1(2):94101.

10. Kristanti E, Lasi F. Psikoedukasi dan Pelatihan "EDA"(Ekspresi Diri Untuk Asertif) Sebagai Upaya Mencegah Seks Bebas Pada Remaja. :15.

11. Amaliyah K, Filliani R, Hidayat Dr. Pengaruh Teknik Assertive Training 
Untuk Meningkatkan Asertivitas Terhadap Perilaku Seksual Dalam Berpacaran Pada Siswi Kelas VIII (Studi Kuasi Eksperimen Di SMP Diponegoro 1 Jakarta). Insight. 2016 Dec 31;4(1):57.

12. Windaniati. Meningkatkan Self-Esteem Siswa Melalui Teknik Asertif Training Pada Siswa Kelas XI TMO 1 SMK Negeri 7 Semarang. Jurnal Penelitian Pendidikan. 2013;30(2).

13. Lioni A, Pratiwi Ti. "Penerapan Assertive Training Untuk Mengurangi Perilaku Negatif Berpacaran Pada Siswa Kelas X-1 di SMA Negeri 1 Porong." Jurnal BK Unesa. 2013;04 (01):23-7.

14. Harsanti IP. Pengaruh Latihan Asertif Terhadap Perilaku Seksual Beresiko Pada Remaja Di SMK Negeri " $X$ " Jember. Program Studi Ilmu Keperawatan Universitas Jember. 2012; 